\title{
MINIMIZING INJURY EFFECTS OF LOW TEMPERATURE ON EGGPLANT (SOLANUM MELONGENA L.) DURING LATE FALL SEASON BY USING SOME PHYSIOLOGICAL TREATMENTS AND ITS REFLECTS ON GROWTH, YIELD, ITS COMPONENTS AND FRUIT QUALITY UNDER TWO DATES OF PLANTING
}

\author{
M. A. Abdel-Aziz and R. H. M. Geeth \\ Self-Pollination Veget. Dept.; Hort. Res. Inst.; Agric., Res. Center, Giza, Egypt. \\ Corresponding author: E-mail:drmedhataziz@yahoo.com \\ Received: Apr. 20, 2019 \\ Accepted: May. 4, 2019

\begin{abstract}
This study was carried out at Sids Horticulture Research Station, Bani Sueif Governorate, Agriculture Research Center, Egypt during the two late fall seasons of 2016/2017 and 2017/2018 seasons, respectively. The objectives of this study were to investigate the proper planting date from two dates i.e. at the middle of September and at the middle of October, foliar spraying with six treatments stimulative i.e. amino acids (as amino zeid $85 \%$ ) at $0.5 \mathrm{~g} / \mathrm{L}$, proline at $0.5 \mathrm{~g} / \mathrm{L}$, pho- $\mathrm{k} 2.5 \mathrm{~g} / \mathrm{L}$, green top star at $2.5 \mathrm{~cm}^{3} / \mathrm{L}$, adenosine triphosphate (ATP) at $0.2 \mathrm{~g} / \mathrm{L}$, mixture consists of potassium oxide (50\% W/V) at $2.5 \mathrm{~cm}^{3}$ plus phosphoric acid (85\%) at $1.5 \%$ and micronized sulpher (85\%) at $2.5 \mathrm{~g} / \mathrm{L}$ as well as the control treatment (spraying with tap water) in addition to their interactions under the condition of low temperature, on the vegetative growth parameters, number of days to $50 \%$ of flowering plants, number of flowers/ plant, fruit set \%, yield and its components (ton/ fed.), fruit quality, some chemical contents in the fruits and cold injury index (\%) as well as cold tolerance index (\%) of eggplant plants (Solanum melongena L.) Black berry $\mathrm{F1}$. The experimental design was split-plot, where the two planting dates were assigned in the main plots and the previous foliar spray treatments were randomly distributed in the sub plots with three replications per treatment. The results of the experiment demonstrated that:
\end{abstract}

The surpass planting date under this investigation was at the middle of September which was occurred the highest significantly increases in the vegetative growth characters, the earlier of flowering, the marketable and total yield, fruit quality, concentrate each of the total chlorophyll contents in the fresh leaves, the total sugars contents in dry fruit, the cold tolerance index (\%) and decreasing the cold injury index (\%) as well as the unmarketable fruits yield as compared with the later planting date i.e. at the $15^{\text {th }}$ of October which gave the lowest values of the all previous traits beside of delaying the flowering, increasing the un-marketable yield, the cold injury index (\%) of the plants and decreasing the tolerance index (\%) under this conditions of low temperature. No significant values were detected in fruit set \%, ascorbic acid contents in the fresh fruits and the total phenol contents in the dry fruit, between the $1^{\text {st }}$ and the $2^{\text {nd }}$ planting dates in the two late fall seasons, respectively.

Regarding to the marked stimulatory effect of spraying with some stimulative treatments, it was concluded that, foliar spraying with green top star at $2.5 \mathrm{~cm}^{3} / \mathrm{L}$ followed by amino zied at $0.5 \mathrm{~g} / \mathrm{L}$ then the mixture consists of potassium oxide at $2.5 \mathrm{~cm}^{3}$ plus phosphoric acid at $1.5 \%$ and micronized sulpher at $2.5 \mathrm{~g} / \mathrm{L}$ significantly increased the vegetative growth characters, the earlier of flowering, number of flowers/ plant, fruit set \%, the marketable and total yield (ton/ fed.), the total chlorophyll, fruit quality, ascorbic acid, the 
total sugars, the total phenol, the cold tolerance index (\%) and decreasing the cold injury index (\%) as well as the un-marketable fruits yield.

On the contrary, the lowest results of all the previous characters were obtained when the plants foliared with proline at $0.5 \mathrm{~g} / \mathrm{L}$ followed by adenosine triphosphate at $0.2 \mathrm{~g} / \mathrm{L}$ as compared with the control (untreated plants) which sprayed with tap water.

Concerning to, the results of the interactions between the two studied factors i.e. planting dates and spraying with some treatments were used in this investigation elucidated that, the surpassing interactions treatment which was occurred with the highest means values over all the other interactions were obtained by the interaction between the $1^{\text {st }}$ planting date at the middle of September and foliar spraying eggplant plants with green top star at $2.5 \mathrm{~cm}^{3} / \mathrm{L}$ followed by amino zied at $0.5 \mathrm{~g} / \mathrm{L}$ then the treatment of potassium oxide at $2.5 \mathrm{~cm}^{3}$ plus phosphoric acid at $1.5 \%$ and micronized sulpher at $2.5 \mathrm{~g} / \mathrm{L}$, which produced significant increases of the marketable and total yield, fruit quality, the cold tolerance index (\%) as well as decreasing the un- marketable yield and the cold injury index (\%) as compared with the rest of the interactions, these findings were true in the both late fall seasons, and this superior results continued until the beginning of summer season.

Key words: Eggplant, Planting dates, Low temperature, Green top star, Fruit quality, Cold injury index (\%) and Cold tolerance index (\%).

\section{INTRODUCTION}

Eggplant (Solanum melongena L.) also, called aubergine or brinjal, is one of the top ten vegetable crops in the world. Its ranked amongst the top ten vegetables in terms of flavonoic and polyphenols constituents and including hydroxycinnamic acid and its derivative chlorogenic acid in flesh, which have a potent antioxidant capability which are effective for curing many numbers of diseases, including cancer, high blood pressure and hepatitis. Eggplant fruits are known for being low in calories and having a rich source of minerals composition which beneficial for human health i.e. potassium, magnesium, calcium and iron (Umesh et al., 2015).

Eggplant plants consider warmclimate vegetables, it's found in tropical and subtropical climates worldwide. Eggplant plants are subjected to various abiotic stresses i.e. cold stress, which it was defined as the temperature in a range low enough to suppress the growth without causing cellular functions, low temperature is the most important environmental factor limiting the productivity and geographical distribution of eggplants across the world. It is known that induce several abnormalities at various levels of cell organization, damage of chilling stress can happen by range of $10-15^{\circ} \mathrm{C}$ temperature and that may occur at any stage of eggplant growth and development. chilling also, induce the overproduction of reactive oxygen species (ROS) that can promote oxidative stress in lipids, proteins and nucleic acids, various symptoms of chilling of eggplant include reducing leaf expansion, wilting, chlorosis (yellowing of leaves) and may lead to necrosis (death of tissue) surface scald as, Alternaria rot, surface pitting, browning of the flesh and seeds chilling also, causing severely hampers the reproductive development (Alexander et al., 2012).

Concerning to, planting dates, determining suitable planting date plays an important role in conformation of the plant growth stages with desirable 
environmental conditions which results in a maximum fruit yield components and quality. So that, the late planting decreases the vegetative growth and flowering buds which can be injured specially by low temperature which is consider to be one of the major abiotic stresses inducing negative effects on the plant growth and finally causes a remarkable reduction in total yield as results of increasing the production of toxic reactive oxygen species. In this respect, climate change is a major threat for crop production all over the world. The meteorological data for last 10 years indicated that the crop suffers from the cold injury index (\%) during the month of January which results in low yield (Harlan and Raymond, 2015).

Several investigators found that, it can by using some stimulative compounds as foliar spray under low temperature condition led to inducing more tolerance against chilling injury as the following:-

Regarding to, amino acids and proline as foliar treatments, amino acids is known as a well biostimulant which can directly or indirectly influence the physiological activities of has positive effects on the plant growth, yield and significantly minimized the injury caused by abiotic stress i.e. chilling. Amino acids are fundamental ingredients in the process of protein synthesis; about 20 important amino acids are involved in the process of each function. The requirement of amino acids in essential qualities ensure rapid and easy transport of nutrients into most deficient areas of the plants, by increasing the leaf area, chlorophyll content and photosynthesis rate, it is thus led to obtain higher crop yields with better quality.

The accumulation of proline in the plant tissues in response to different abiotic stress i.e. chilling, proline may play an important role against oxidative damages caused by reactive oxygen species due to its action as a single oxygen quencher. Proline promotes the deposition of useable nitrogen and enhances membrane stability under stressed conditions. Under stressed conditions, trigger the accumulation of proline in the plant tissues and are responsible for better growth and productivity. Lipid peroxidation induced by chilling and oxidative stress was effectively overcome by exogenous proline application which was acted as active oxygen, stabilizing membranes, acted as a source of nitrogen and carbon (Szabados and Savoure, 2010).

Regarding to the pho-k, adenosine triphosphate, green top star and mixture of potassium oxide, phosphoric acid and micronized sulpher as foliar treatments, in this connection, mineral nutrition of the plants plays a critical role in increasing the plant growth, reproductive stage and production as well as resistance to environmental stresses i.e. low temperature.

With respect to, macro element of phosphorus (P) its one of the major nutrients that the plant need it in large amounts it constitutes about $0.2 \%$ of the plant dry weight, for its role in many metabolic and physiological processes as it is involved in the synthesis of nucleic acids and stimulate growth and development of early and healthy roots, which is associated with water absorption. It's involved in high energy transfer compounds such as adenosine diphosphate, adenosine triphosphate and plays a key role in energy transfer in the metabolic processes. Phosphorus contributes to several vital functions in the plant, such as improving winter hardiness, increase cell division, photosynthesis, transformation of sugars and starches and regulation of some enzymes, enhanced flowering time, number, size and the dry weight of flowers per plant. 
Under phosphorus deficiency, if it expose to chilling, the plants leads to multiple changes in their membranes, namely reduce the membrane elasticity, decreasing their compliance and preventing lipid inclusion in their composition, lower lipid fluidity causes degradation of phospholipids, resulting in increased free fatty acids.

As for, the macro element potassium (K) is consider as an important nutrient for plant meristematic growth and physiological functions, including regulation of water, gas exchange in the plants, protein synthesis, enzyme activation, photosynthesis and carbohydrate translocation in plants, $\mathrm{CO}_{2}$ assimilation and facilitates carbon movements. Potassium also, has favorable effects on metabolism of nucleic acids, vitamins and growth substances.

Under low temperature stress, the fluidity of membrane lipids thus may alters membrane structure. Low temperature also, affects photosynthetic electron transport, stomatal conductance, rubisco activity, and $\mathrm{CO}_{2}$ fixation in the plants due to conversion of $\mathrm{O}_{2}$ to reactive oxygen species. Potassium plays a crucial role in survival of crop plants under environmental stress conditions, potassium is essential for many physiological processes, such as photosynthesis, translocation of photosynthates into sink organs, maintenance of turgidity and activation of enzymes under stress conditions. Under high amounts of potassium can provide protection against oxidative damage caused by chilling or frost (Njira and Nabwami, 2015).

Concerning to, magnesium (Mg) as a macro element, it is involved in numerous physiological as one of the essential elements in the chlorophyll molecule and plays a vital role in carbohydrate synthesis and this due to activation of many enzymes. Its maintenance of adequate magnesium nutrition at the late growth stages is also, essential for minimizing generation of harmful reactive oxygen species and photo oxidative damage in the chloroplasts. Magnesium increases the root growth and root surface area which helps to increase uptake of water and nutrients by root. Magnesium also, increases the amount of sucrose and enhances the transport of sucrose from leaves to roots, magnesium enhances the photosynthetic rate under temperature stress which in turn improves the productivity, magnesium deficient plants have also, shown to accumulate significantly higher amount of lipid peroxidation (Guo et al., 2016).

Regarding to sulfur (S), it is known that sulfur plays an important role not only in the growth and development of higher plants, but also, associated with increased stress tolerance in the plants. Sulfur deficiency negatively affects the chlorophyll and nitrogen contents of leaves and photosynthetic enzymes. Also, the enhancement effect of sulfur on the growth characters was due to stimulatory effects of sulfur on cell division which helped in leaf expansion and increased light interception improved the vegetative growth, sulfur is necessary for the synthesis of three important essential amino acids such as cystine, cysteine and methionine also, the chlorophyll, vitamins $(B$, biotin and thiamine), metabolism of carbohydrates (Marschner, 2012).

The present study was aimed to identifying the optimal planting dates at the late fall season to producing good marketable eggplant fruits in winter as well as using some stimulative treatments as foliar spraying and their interactions to improve the growth characters, the marketable and total yield, fruit quality in order to ameliorate 
the cold injury index (\%) which was caused by undesirable environmental conditions i.e. chilling stress of eggplant plants specially at the later planting date i.e. at the middle of October.

\section{MATERIALS AND METHODS}

Two field experiments were carried out during the two late fall seasons of 2016/2017 and 2017/2018 at Sids Horticulture Research Station, Bani Sueif Governorate, Agriculture Research Center, Egypt to investigate the effect of planting date, foliar spraying with some stimulate chemical treatments and their interactions under the conditions of undesirable environmental on the vegetative growth parameters, number of days to $\mathbf{5 0} \%$ of flowering plants, number of flowers/ plant, fruit set $\%$, yield and its components, fruit quality and some chemical contents in the fruits, cold injury index (\%) as well as cold tolerance index (\%) of eggplant plants (Solanum melongena L.) Black berry F1.

The experimental design was splitplot with three replicates. The main plots were devoted for the two planting dates as factor $A$ i.e. at the middle of September and the middle of October. Foliar spraying with six treatments as factor B i.e. amino acids (as a commercial compound amino zeid $85 \%$ ) at $0.5 \mathrm{~g} / \mathrm{L}$, proline at $0.5 \mathrm{~g} / \mathrm{L}$, pho-k $2.5 \mathrm{~g} /$ $\mathrm{L}$, adenosine triphosphate (ATP) at $0.2 \mathrm{~g} /$ $\mathrm{L}$, green top star at $2.5 \mathrm{~cm}^{3} / \mathrm{L}$, mixture of potassium oxide at $2.5 \mathrm{~cm}^{3}$ plus phosphoric acid at $1.5 \%$ and micronized sulpher at $2.5 \mathrm{~g} / \mathrm{L}$ as well as the control treatment (spraying with tap water) as sub plots treatments.

The meteorological data for the experimental area was obtained from the Central Laboratory for Agricultural Climate (CLAC), Agricultural Research Center (ARC), Ministry of Agricultural and Land Reclamation. The values were recorded during the two growing seasons at Sids, Bani Sueif Governorate as shown in Table, 1.

Table, 2 shows some Physical and chemical properties of the experimental soil before planting.

Table 1: Meteorological data at Sids, Bani Sueif Governorate region during the two late fall seasons of 2016/2017 and 2017/2018

\begin{tabular}{|c|c|c|c|c|}
\hline \multirow{2}{*}{ Months } & \multicolumn{4}{|c|}{ Air temperature ${ }^{\circ} \mathrm{C}$} \\
\cline { 2 - 5 } & \multicolumn{2}{|c|}{$2016 / 2017$} & \multicolumn{2}{c|}{$2017 / 2018$} \\
\cline { 2 - 5 } & Maximum & Minimum & Maximum & Minimum \\
\hline September & 38.7 & 16.5 & 38.5 & 16.2 \\
\hline October & 31.2 & 14.3 & 29.7 & 13.1 \\
\hline November & 26.1 & 13.3 & 24.6 & 10.9 \\
\hline December & 22.9 & 6.0 & 21.4 & 9.0 \\
\hline January & 21.5 & 8.0 & 19.1 & 5.9 \\
\hline February & 27.0 & 8.9 & 23.9 & 10.2 \\
\hline
\end{tabular}


Table 2: Physical and chemical properties of the experimental soil during the two seasons of 2016 and 2017

\begin{tabular}{|c|c|c|}
\hline Components & 2016 & 2017 \\
\hline Soil Type & \multicolumn{2}{|c|}{ Clay loam } \\
\hline Organic Matter \% & 1.83 & 1.97 \\
\hline Clay \% & 57.10 & 58.00 \\
\hline Silt \% & 26.23 & 24.10 \\
\hline Sand \% & 16.67 & 17.90 \\
\hline PH & 7.60 & 7.90 \\
\hline E C (mmhos / cm) & 0.63 & 0.65 \\
\hline CaCO3 \% & 1.90 & 2.10 \\
\hline Available N (ppm) & 22.40 & 24.30 \\
\hline Available P (ppm) & 15.59 & 13.10 \\
\hline Available K (ppm) & 315.60 & 319.13 \\
\hline
\end{tabular}

The compounds names and its composition, sources as well as their concentrations/ $L$ beside the control are shown in Table, 3. After 45 days from seed sowing in the nursery, uniform eggplant seedlings were transplanted by hand at the fourth and fifth true leaf stage in the open field at $40 \mathrm{~cm}$ apart on one side of the ridge during 2016/2017 and 2017/2018 seasons, respectively. The experimental unit consisted of $12.8 \mathrm{~m}^{2}$ which included 4 rows each of $0.8 \mathrm{~m}$ width and $4 \mathrm{~m}$ length. The different spraying treatments were applied at eight times of each planting date; the $1^{\text {st }}$ foliar spraying started after 15 days from transplanting of the seedlings and was repeated every 15 day intervals during the growth period of the two seasons, respectively.
Guard rows were set between the experimental units to avoid drifting to the adjacent plots. All treatments were applied as a foliar spray on the plants using hand operated compressed air sprayer. All recommended agricultural practices for eggplant plants plantation were followed according to the recommendation of the Egyptian Ministry of Agriculture and Land Reclamation.

\section{Recorded data:}

\section{1-Vegetative growth parameter measurements:}

Five plants were taken randomly from the inner two rows for each sub plot after ten days from the fifth spray (after 85 days from transplanting) to measure the following vegetative growth parameters i.e. plant height $(\mathrm{cm})$, number of branches/ plant and dry weight of leaves/ (g) plant. 
Table 3: The compounds names and its composition, sources and concentration/ $L$ which it's used as a foliar spray during the two growth period under the condition of the two late fall seasons of 2016/2017 and 2017/2018

\begin{tabular}{|c|c|c|c|}
\hline $\begin{array}{c}\text { Compounds } \\
\text { name }\end{array}$ & Composition & Sources & Concentration/ L \\
\hline Amino Zeid ${ }^{\circledast}$ & $\begin{array}{l}\text { Amino Zeid: - (total amino acids } 85 \\
\% \text { contained in L-a type). Typical } \\
\text { amino acids profile (\%):- aspartic } \\
3.29 \% \text {, tyrosine } 0.52 \% \text {, glutamic } \\
8.18 \% \text {, glycin } 2.03 \% \text {, alanine } 2.26 \\
\% \text {, valine } 2.51 \% \text {, isoleucine } 1.11 \% \text {, } \\
\text { Leucine } 2.03 \% \text {, lysine } 1.75 \% \text {, } \\
\text { arginine } 4.64 \% \text {, histidine } 0.56 \% \text {, } \\
\text { proline } 3.96 \% \text {, phenylalanine } 0.99 \\
\% \text {, serine } 4.99 \% \text { and theronine } 3.57 \\
\% \text { Organic nitrogen } 10 \% \text { and } \\
\text { potassium oxide } 2.5 \% \text {. }\end{array}$ & $\begin{array}{l}\text { Amino Zeid is a } \\
\text { trademark } \\
\text { of Union for } \\
\text { Agricultural } \\
\text { Development Co., } \\
\text { Ltd. Cairo - Egypt. }\end{array}$ & $0.5 \mathrm{~g} / \mathrm{L}$ \\
\hline Proline $^{\circledR}$ & $\begin{array}{l}\text { L-Proline } \\
\mathrm{C}_{5} \mathrm{H}_{9} \mathrm{NO}_{2}\end{array}$ & $\begin{array}{l}\text { The importer } \\
\text { company is } \\
\text { Techno Gene } \\
\text { establishment for } \\
\text { importation and } \\
\text { exportation Co., } \\
\text { Ltd. Giza - Egypt. }\end{array}$ & $0.5 \mathrm{~g} / \mathrm{L}$ \\
\hline Pho-k $^{\circledR}$ & $\mathrm{P}_{2} \mathrm{O}_{5}$ at $52 \%-\mathrm{K}_{2} \mathrm{O}$ at $34 \%$ & $\begin{array}{l}\text { Pho-k }^{\circledR} \text { is a } \\
\text { trademark of Union } \\
\text { for Agricultural } \\
\text { Development Co., } \\
\text { Ltd. Cairo - Egypt. }\end{array}$ & $2.5 \mathrm{~g} / \mathrm{L}$ \\
\hline $\begin{array}{c}\text { Adenosine }^{\circledR} \\
\text { triphosphate } \\
\text { (ATP) }\end{array}$ & $\begin{array}{l}\text { Adenosine-5-triphosphoric acid } \\
\text { disodium salt (ATP) } \\
\mathrm{C}_{10} \mathrm{H}_{14} \mathrm{~N}_{5} \mathrm{Na}_{2} \mathrm{O}_{13} \mathrm{P}_{3}\end{array}$ & $\begin{array}{l}\text { The importer } \\
\text { company is } \\
\text { Techno Gene } \\
\text { establishment for } \\
\text { importation and } \\
\text { exportation Co., } \\
\text { Ltd. Giza - Egypt. }\end{array}$ & $0.2 \mathrm{~g} / \mathrm{L}$ \\
\hline $\begin{array}{l}\text { Green top } \\
\text { star }^{\circledR}\end{array}$ & $\begin{array}{c}\text { Consists of magnesium oxide (5\%), } \\
\text { sulfur trioxide (10\%), magnesium } \\
\text { alginate, natural antioxidants, UVA } \\
\text { protection materials, tocinins, auxins } \\
\text { and vitamins derived from marine } \\
\text { algae. }\end{array}$ & $\begin{array}{l}\text { Green top star is } \\
\text { a trademark of } \\
\text { Shoura Chemicals } \\
\text { Co., Ltd. Giza - } \\
\text { Egypt. }\end{array}$ & $2.5 \mathrm{~cm}^{3} / \mathrm{L}$ \\
\hline \multicolumn{4}{|c|}{$\begin{array}{l}\text { Mixture consists of:- Potassium oxide }(50 \% \mathrm{~W} / \mathrm{V}) \text { at } 2.5 \mathrm{~cm}^{3} \text { plus phosphoric acid (85 } \\
\%) \text { at } 1.5 \% \text { and micronized wettable sulpher }(85 \%) \text { at } 2.5 \mathrm{~g} / \mathrm{L} \text {. }\end{array}$} \\
\hline Control & \multicolumn{3}{|c|}{ Spraying with tap water } \\
\hline
\end{tabular}


2-Flowering characters:

2-1- Number of days taken for $50 \%$ of flowering plants: Number of days taken from the date of transplanting to flowering of the $50 \%$ plants/ plot in each treatment was recorded.

\section{2-2- Number of flowering/ plant.}

2-3- Fruit set \%: Estimated with an average of twenty flowers at five plantsl plot after 85 days from transplanting in the two seasons using the following equation:

- Fruit set $\%=$ No. of fruits $I$ No. of flowers $\times 100$

\section{3-Yield and its components (ton/} fed.):

3-1-Fruit weight: Includes average of the representative sample of five eggplant fruits taken from the $3^{\text {rd }}$ picking.

3-2-Early yield: Includes weight of the first three pickings.

3-3-Marketable yield: At harvested time, the commercial maturity stage which includes all the fruits reached to the full size its characterized to be intact, straight with a fresh appearance and without any pest defects, diseases and the undeformed.

3-4-Un-marketable yield: Includes defective, malformed, pale colored, broken, overgrown, short and small fruits, symptoms of pest and disease damage were considered the unmarketable.

3-5-Total yield: Includes all the numbers of harvested fruits collecting from the outer two rows along of the two late fall seasons, respectively.

\section{4-Fruit quality characters:}

A representative sample of five eggplant fruits from each experimental plot of the outer two rows at the marketable ripe stage which was taken from the $3^{\text {rd }}$ picking to determine ascorbic acid (Vitamin C), content in eggplant fruit tissues (mg/100 $\mathrm{g}$ fresh weight) according to the method mentioned in the (A.O.A.C., 2005).

\section{5-Chemical determinations: \\ Fresh samples of eggplant fruits were} dried in an electric forced-air oven at $\mathbf{7 0}$ ${ }^{\circ} \mathrm{C}$ to constant weight then fractionated and sifting. The fine powder (at $0.2 \mathrm{~g}$ ) of each dry sample was digested in a mixture of sulphuric and perchloric acids, as wet digestion according to Chapman and Paratt (1961).

5-1- Photosynthetic pigments: The total chlorophyll content ( $\mathrm{mg} / \mathbf{1 0 0} \mathrm{g}$ fresh weight) was determined in the fresh leaves after ten days from the fifth spray, according to the method described by Nagata and Yamashita (1992).

5-2- Total sugars contents (\%): Were determined in dry fruit according to Dubois et al. (1975).

5-3- Total phenol contents $(\mathrm{mg} / \mathrm{g})$ : Were determined in dry fruit according to the method described by (Wettasinghe and Shahidi, 1999).

\section{6- Cold measurements (\%):}

6-1- Cold injuryl plant (\%).

Cold injury symptoms of eggplant plants tissues were visually evaluated on a subjective scale. Injury level was expressed according to a modification of the scale proposed by (Wilson and Greaves, 1990) and the cold injury index (\%) was calculated according to the following formula as follows:

Cold injury index $(\%)=$ Injury level $x$ Number of plants on the levell Total number of plants in the treatment $\times \mathbf{1 0 0}$ 
The numerical injury level of the cold injury index is: $5=$ severe damage, $4=$ moderate damage, $3=$ regular damage, 2 $=$ low damage and $1=$ no damage as average for each plot.

\section{6-2- Cold tolerance index I plant (\%).}

Cold tolerance index (\%) was calculated according to minus the value of the cold injury index (\%) from the 100 $\%$ of the average total plants/ plot.

\section{7-Statistical analysis:}

All obtained data of the present study were subjected to the analysis of variance techniques according to the design used by the MSTATC computer software program variance and the mean of treatments were compared according to the Least Significant Differences ( $L S$ D) test at the 0.05 probability level, the method described by Bricker (1991).

\section{RESULTS AND DISCUSSION}

\section{1-Vegetative growth parameters of}

eggplant plants:

1-1-Effect of planting dates:

The data of the vegetative growth characteristics, i.e. plant height, number of branches/ plant and the dry weight of leaves/ plant as affected by planting dates, spraying with some stimulative treatments and their interactions are given in Table, 4 . It is clear that, there were significant differences occurred in the several vegetative growth parameters of the eggplant plants, which indicated that, the $1^{\text {st }}$ planting date i.e. at the $15^{\text {th }}$ of September was considered the best planting time for majority of the growth parameters, which gave the tallest plant height, the highest number of branches/ plant and the heaviest dry weight of leaves/ plant, while the lowest values of the previous traits were recorded at the later planting date i.e. at the $15^{\text {th }}$ of October in the $1^{\text {st }}$ and the $2^{\text {nd }}$ seasons, respectively.
It is known that, the optimum temperature of eggplant ranges between 22-30 ${ }^{\circ} \mathrm{C}$, the optimum temperature for eggplant seed germination ranges from $24^{\circ} \mathrm{C}$ to $29^{\circ} \mathrm{C}$, for the optimal vegetative growth a temperature of $30^{\circ} \mathrm{C}$, for growth and fruit development $21^{\circ} \mathrm{C}$ to $29^{\circ} \mathrm{C}$ and for the reproductive phases $22^{\circ} \mathrm{C}$.

Additionally, cultivation of eggplant plants in the late stages of fall season from September to November, during this time the temperature decreased strongly, which severity reducing flower inflorescence, fruit set $\%$ as well as loss the fruit yield specially when the temperature becomes less than 22.9, 6.0, 21.4 and $9.0{ }^{\circ} \mathrm{C}$ which recorded at day and night in December, while recorded 21.5, 8.0, 19.1 and $5.9^{\circ} \mathrm{C}$ at day and night as recorded in January as shown in meteorological data at Table, 1 in the $1^{\text {st }}$ and the $2^{\text {nd }}$ late fall seasons, respectively (Inthichack et al., 2013).

In this connection, the optimum temperature prevailing in the $1^{\text {st }}$ planting date may be to produce healthy plants which lead to encourage the formation of higher photosynthates which reflected on the fresh and dry weight of leaves values than the $2^{\text {nd }}$ planting date. On the other hand, the abundance of the growth characters of eggplant which planting in the $1^{\text {st }}$ planting date under this investigation may be attributed to the long time of the plants which exposed to it during the growth stage and higher solar radiation led to the increase of the potential photosynthesis production as well as the longer the duration of the growth period, consequently produce the better growth characters as compared with the later planting date which indicated that, a deceasing trends towards of the vegetative growth. The same general trend were reported by Islam et al. (2010) who proposed that planting at the $15^{\text {th }}$ of September gave significant higher values on the plant 
height, number of leaves/ plant and branches/ plant as compared with the other planting date at the $15^{\text {th }}$ of October which gave the lowest values of vegetative growth traits of sweet pepper plants.

Table 4: Effect of planting dates, spraying with some stimulative treatments and their interactions on plant height, number of branches and dry weight of leaves/ plant of the eggplant plants during the two late fall seasons of 2016/2017 and 2017/2018

\begin{tabular}{|c|c|c|c|c|c|c|c|}
\hline \multirow{2}{*}{$\begin{array}{c}\text { Effect of } \\
\text { planting } \\
\text { dates }\end{array}$} & \multirow[b]{2}{*}{ Treatments } & \multicolumn{3}{|c|}{$1^{\text {st }}$ Season } & \multicolumn{3}{|c|}{$2^{\text {nd }}$ Season } \\
\hline & & $\begin{array}{l}\text { Plant } \\
\text { height } \\
\text { (cm) }\end{array}$ & $\begin{array}{c}\text { Number of } \\
\text { branches/ } \\
\text { plant }\end{array}$ & $\begin{array}{c}\text { Dry } \\
\text { weight } \\
\text { of leaves } \\
\text { (g)/ plant }\end{array}$ & $\begin{array}{c}\text { Plant } \\
\text { height } \\
\text { (cm) }\end{array}$ & $\begin{array}{c}\text { Number of } \\
\text { branches } \\
\text { plant }\end{array}$ & $\begin{array}{c}\text { Dry } \\
\text { weight } \\
\text { of leaves } \\
\text { (g)/ plant }\end{array}$ \\
\hline \multirow{7}{*}{$\begin{array}{l}1^{\text {st }} \text { date } \\
\text { at } 15 / 9\end{array}$} & Amino Zeid ${ }^{\circledR}$ & 66.8 & 5.6 & 32.2 & 66.6 & 5.5 & 31.6 \\
\hline & Proline $^{\circledR}$ & 61.1 & 4.2 & 27.1 & 61.2 & 4.4 & 26.5 \\
\hline & Pho-k $^{\circledR}$ & 63.3 & 4.8 & 30.3 & 62.7 & 4.7 & 29.6 \\
\hline & Green top star ${ }^{\circledR}$ & 70.0 & 5.8 & 34.3 & 69.3 & 5.8 & 33.6 \\
\hline & Adenosine triphosphate ${ }^{\circledR}$ & 62.2 & 4.6 & 28.4 & 62.2 & 4.5 & 27.8 \\
\hline & Mixture of $\mathrm{K}_{2} \mathrm{O}+\mathrm{H}_{3} \mathrm{PO}_{4}+\mathrm{S}$ & 64.5 & 5.4 & 31.2 & 64.2 & 5.4 & 30.5 \\
\hline & Control (Tap water) & 60.0 & 4.0 & 25.4 & 59.4 & 4.2 & 24.9 \\
\hline \multicolumn{2}{|r|}{ Mean } & 63.9 & 4.9 & 29.8 & 63.7 & 4.9 & 29.2 \\
\hline \multirow{7}{*}{$\begin{array}{l}2^{\text {nd }} \text { date } \\
\text { at } 15 / 10\end{array}$} & Amino Zeid ${ }^{\circledR}$ & 55.5 & 4.3 & 29.1 & 55.3 & 4.0 & 28.8 \\
\hline & Proline $^{\circledR}$ & 50.4 & 3.1 & 23.5 & 50.1 & 2.9 & 23.5 \\
\hline & Pho-k ${ }^{\circledR}$ & 51.8 & 3.4 & 25.8 & 52.2 & 3.3 & 24.7 \\
\hline & Green top star ${ }^{\circledR}$ & 57.5 & 4.5 & 30.9 & 57.9 & 4.1 & 31.6 \\
\hline & Adenosine triphosphate ${ }^{\circledR}$ & 50.8 & 3.2 & 24.6 & 51.0 & 3.1 & 23.9 \\
\hline & Mixture of $\mathrm{K}_{2} \mathrm{O}+\mathrm{H}_{3} \mathrm{PO}_{4}+\mathrm{S}$ & 53.1 & 4.1 & 27.9 & 53.6 & 3.9 & 26.5 \\
\hline & Control (Tap water) & 48.3 & 2.7 & 22.1 & 48.7 & 2.6 & 21.4 \\
\hline \multicolumn{2}{|r|}{ Mean } & 52.5 & 3.6 & 26.3 & 52.7 & 3.4 & 25.8 \\
\hline \multirow{7}{*}{ Average } & Amino Zeid ${ }^{\circledR}$ & 61.1 & 5.0 & 30.7 & 61.0 & 4.8 & 30.2 \\
\hline & Proline $^{\circledR}$ & 55.7 & 3.7 & 25.3 & 55.6 & 3.6 & 25.0 \\
\hline & Pho-k ${ }^{\circledR}$ & 57.5 & 4.1 & 28.0 & 57.5 & 4.0 & 27.2 \\
\hline & Green top star $^{\circledR}$ & 63.6 & 5.2 & 32.6 & 63.6 & 4.9 & 32.6 \\
\hline & Adenosine triphosphate ${ }^{\circledR}$ & 56.5 & 3.9 & 26.5 & 56.6 & 3.8 & 25.8 \\
\hline & Mixture of $\mathrm{K}_{2} \mathrm{O}+\mathrm{H}_{3} \mathrm{PO}_{4}+\mathrm{S}$ & 58.8 & 4.8 & 29.5 & 58.9 & 4.6 & 28.5 \\
\hline & Control (Tap water) & 54.2 & 3.4 & 23.8 & 54.1 & 3.4 & 23.1 \\
\hline \multirow{3}{*}{$\begin{array}{c}\text { LSD at } \\
0.05\end{array}$} & Planting dates & 8.1 & 0.8 & 3.2 & 6.8 & 1.3 & 2.7 \\
\hline & Treatments & 1.2 & 0.5 & 0.9 & 1.3 & 0.4 & 1.2 \\
\hline & Interaction & 1.7 & 0.2 & 1.2 & 1.1 & 0.3 & 1.6 \\
\hline
\end{tabular}




\section{1-2-Effect of spraying of some stimulative treatments:}

Regarding to, the data of the plant height, number of branches/ plant and the dry weight of leaves/ plant as influenced by various spraying with some stimulative treatments i.e. amino zeid, proline, pho-k, adenosine triphosphate, green top star, mixture of potassium oxide plus phosphoric acid and micronized sulpher are given in the same Table, 4 . The results revealed that the plant height, number of branches/ plant and dry weight of leaves/ plant in the two late fall seasons were significantly affected by foliar spraying with green top star followed by amino zied then the mixture of potassium oxide plus phosphoric acid and micronized sulpher. The results of the present investigation also, demonstrated that, the lowest result was occurred with the foliar application by proline followed by adenosine triphosphate as compared to the control (untreated plants) which sprayed with tap water in the $1^{\text {st }}$ and the $2^{\text {nd }}$ seasons, respectively.

Referring to, the positive effects of the stimulative amino acids and proline foliar treatments, amino acids can directly or indirectly influence the physiological activities growth and development, delay plant senescence as well as its increase the antioxidant content in the leaves of the plant. Amino acids also, help many symbiotic processes that improve many aspects of plants which can be activators or precursors of phytohormones and growth substances like, L-tryptophan which is a precursor for auxin synthesis which affect cellular metabolism in treated plants leading to enhanced growth and tomato yield (Boras et al., 2011).

The present results were agreed with that reported by Mahmoud et al. (2017) they investigated that the foliar spraying of sweet pepper plants with the amino acids at the rate of $2 \mathrm{~g} / \mathrm{L}$ significantly increased the fresh and dry weight gl plant. ElSayed et al. (2015) studied that foliar application of eggplant with proline at the rate of $100 \mathrm{mg} / \mathrm{L}$ significantly increased plant height, number of leaves, number of branches, fresh weight and dry weight.

Regarding to the pho-k, adenosine triphosphate, green top star and mixture of potassium oxide, phosphoric acid and micronized sulpher as foliar treatments, in parallel to the above finding was obtained by Abdel-Aziz and Geeth (2018) they generalized that foliar spraying tomato plants with green top star at 2.5 $\mathbf{c m}^{3}$ I L significantly increased plant height, number of branches, fresh and dry weight of the leaves per plant. AbdelAziz and Afsah (2018) assumed that foliar spraying Cape gooseberry plants by solfan (liquid sulfur $70 \% \mathrm{SC}$ ) at the rate of $2 \mathrm{~cm}^{3} / \mathrm{L}$ significantly enhanced the plant height, number of branches and leaves, fresh and dry weight of leaves/ plant. Hegazi et al. (2017) who postulated that foliar application by potassium as $\mathrm{K}_{2} \mathrm{O}$ at the rate of $200 \mathrm{ppm} / \mathrm{L}$ occurred significantly improved the plant height, number of leaves and branches, fresh and dry weight of the leaves per plant of sweet pepper fruits. Abdel-Hakim et al. (2012) decided that foliar application of snap bean plants with adenosine triphosphate at the rate of $180 \mathrm{ppm}$ significantly increased plant height, number of branches, fresh and dry weight of the leaves/ plant.

\section{1-3-Effect of the interactions:}

As for, the effect of the interactions between the two factors i.e. planting dates and foliar spraying with some stimulative treatments on the vegetative growth parameters of eggplant plants, the results in Table, 4 showed that, the $1^{\text {st }}$ planting date at the middle of September and foliar spraying with green top star 
followed by amino zied and mixture of potassium oxide plus phosphoric acid and micronized sulpher were occurred the best interactions which produced the highest values over the other interactions treatments.

On the contrary, the lowest records on the vegetative growth parameters were obtained with the interactions between the $2^{\text {nd }}$ planting date at the middle of October and the foliar spraying with proline followed by adenosine triphosphate during the two growing late fall seasons. The present results corresponds to the results reported by Abdel-Hakim et al. (2012) they mentioned that the interaction of the $1^{\text {st }}$ sowing date i.e. at the $25^{\text {th }}$ of October on snap bean plants and foliar application with adenosine triphosphate at the rate of $\mathbf{1 8 0}$ ppm was occurred the highest mean values of plant height, number of branches, fresh and dry weight of the leaves/ plant. Whereas, the lowest interaction was obtained with the $2^{\text {nd }}$ sowing date i.e. at the $15^{\text {th }}$ of November as well as foliar application with adenosine triphosphate at the rate of 60 ppm.

\section{2-Flowering characters of} eggplant plants:

2-1-Effect of planting dates:

The effect of planting dates and foliar spraying with some stimulative treatments and their interactions on number of days to $50 \%$ of flowering plants, number of flowers/ plant and fruit set $\%$ illustrated in Table, 5 which exhibited marked influences on all values of the previous traits of eggplant plants flowering. The results revealed that, planting date at the $15^{\text {th }}$ of September explicated the significant higher values for $50 \%$ flowering and number of flowers/ plant as compared with the later planting date i.e. at the $15^{\text {th }}$ of October which were obtained the later for number of days to $50 \%$ of flowering plants and the lowest number of flowers/ plant in the $1^{\text {st }}$ and the $2^{\text {nd }}$ seasons, respectively. No significant values were detected in fruit set $\%$ between the $1^{\text {st }}$ and the $2^{\text {nd }}$ planting dates at the two late fall seasons, respectively.

In this connection, during the reproductive development low temperature stress induces flower abscission, pollen sterility, pollen tube distortion, ovule abortion and reduced fruit set $\%$, which ultimately lowers yield and its components (Alexander et al., 2012). The same results were stated by Singh et al. (2015) who pointed out that planting at the $15^{\text {th }}$ of September significantly increased the mean values of $50 \%$ flowering plants as compared with the $3^{\text {rd }}$ planting date at the $15^{\text {th }}$ of October of tomato fruits.

\section{2-2-Effect of spraying of some stimulative treatments:}

The data presented in the same Table, 5 revealed obviously that the effect of spraying with some stimulative treatments i.e. amino zeid, proline, pho-k, adenosine triphosphate, green top star, mixture of potassium oxide plus phosphoric acid and micronized sulpher on $50 \%$ flowering, number of flowers/ plant and fruit set \%, it was found that, the superior treatments which attained to the maximum height of all the previous traits i.e. green top star followed by amino zied then the mixture of potassium oxide plus phosphoric acid and micronized sulpher. The results of the present investigation also, showed that, the lowest result executed by foliar spraying with proline followed by adenosine triphosphate as compared with the control treatment during the two late fall seasons, respectively.

As for, the surpassing effects of the amino acids and proline as foliar treatments, amino acids and proline foliar directly before flowering increases the 
chance of obtaining high yields, because this causes positive influences of pollen fertility and thus are essential for good pollination, they increase pollen germination and the length of the pollinic tube, which improves fruit set \%, strengthens cell walls for longer shelf life and helps improve the ripening stage of fruits. Also, lysine, methionine and glutamic acid contribute to the pollination, as they stimulate the pollen grain to germinate and activate pollen tube growth (Szabados and Savoure, 2010).

Table 5: Effect of planting dates, spraying with some stimulative treatments and their interactions on number of days to $\mathbf{5 0} \%$ of flowering plants, number of flowers/ plant and fruit set \% of the eggplant plants during the two late fall seasons of 2016/2017 and 2017/2018

\begin{tabular}{|c|c|c|c|c|c|c|c|}
\hline \multirow{2}{*}{$\begin{array}{c}\text { Effect of } \\
\text { planting } \\
\text { dates }\end{array}$} & \multirow[b]{2}{*}{ Treatments } & \multicolumn{3}{|c|}{$1^{\text {st }}$ Season } & \multicolumn{3}{|c|}{$2^{\text {nd }}$ Season } \\
\hline & & $\begin{array}{c}\text { Number } \\
\text { of days to } \\
50 \% \text { of } \\
\text { flowering } \\
\text { plants }\end{array}$ & $\begin{array}{c}\text { Number } \\
\text { of flowers/ } \\
\text { plant }\end{array}$ & $\begin{array}{c}\text { Fruit } \\
\text { set } \\
(\%)\end{array}$ & $\begin{array}{c}\text { Number of } \\
\text { days } \\
\text { to } 50 \% \text { of } \\
\text { Flowering }\end{array}$ & $\begin{array}{c}\text { Number } \\
\text { of } \\
\text { flowers/ } \\
\text { plant }\end{array}$ & $\begin{array}{c}\text { Fruit set } \\
(\%)\end{array}$ \\
\hline \multirow{7}{*}{$\begin{array}{l}1^{\text {st }} \text { date } \\
\text { at } 15 / 9\end{array}$} & Amino Zeid ${ }^{\circledR}$ & 42.4 & 33.0 & 77.4 & 42.8 & 32.9 & 77.2 \\
\hline & Proline $^{\circledR}$ & 44.4 & 29.4 & 69.3 & 46.4 & 29.5 & 68.8 \\
\hline & Pho-k ${ }^{\circledR}$ & 44.1 & 31.6 & 72.6 & 45.0 & 31.0 & 72.3 \\
\hline & Green top star ${ }^{\circledR}$ & 40.9 & 36.1 & 81.4 & 40.5 & 37.2 & 82.1 \\
\hline & 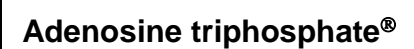 & 45.4 & 30.5 & 71.1 & 45.4 & 30.1 & 71.4 \\
\hline & Mixture of $\mathrm{K}_{2} \mathrm{O}+\mathrm{H}_{3} \mathrm{PO}_{4}+\mathrm{S}$ & 43.1 & 32.2 & 74.7 & 43.7 & 31.6 & 74.0 \\
\hline & Control (Tap water) & 50.0 & 28.9 & 66.3 & 49.7 & 28.5 & 66.5 \\
\hline \multicolumn{2}{|r|}{ Mean } & 44.3 & 31.7 & 73.3 & 44.8 & 31.5 & 73.2 \\
\hline \multirow{7}{*}{$\begin{array}{c}2^{\text {nd }} \text { date } \\
15 / 10\end{array}$} & Amino Zeid $^{\circledR}$ & 46.3 & 27.8 & 74.7 & 45.3 & 27.6 & 74.5 \\
\hline & Proline ${ }^{\circledR}$ & 49.3 & 24.2 & 66.8 & 49.1 & 23.9 & 65.5 \\
\hline & Pho-k $^{\circledR}$ & 47.0 & 26.3 & 70.3 & 46.3 & 25.6 & 71.3 \\
\hline & Green top star ${ }^{\circledR}$ & 44.7 & 31.1 & 77.4 & 44.3 & 30.9 & 77.1 \\
\hline & Adenosine triphosphate ${ }^{\circledR}$ & 48.5 & 25.1 & 68.1 & 47.9 & 24.8 & 67.9 \\
\hline & Mixture of $\mathrm{K}_{2} \mathrm{O}+\mathrm{H}_{3} \mathrm{PO}_{4}+\mathrm{S}$ & 47.4 & 27.1 & 72.1 & 46.7 & 26.5 & 72.8 \\
\hline & Control (Tap water) & 51.6 & 24.0 & 63.1 & 51.5 & 23.1 & 63.4 \\
\hline \multicolumn{2}{|r|}{ Mean } & 47.8 & 26.5 & 70.3 & 47.3 & 26.1 & 70.4 \\
\hline \multirow{7}{*}{ Average } & Amino Zeid $^{\circledR}$ & 44.4 & 30.4 & 76.1 & 44.1 & 30.3 & 75.9 \\
\hline & Proline $^{\circledR}$ & 46.8 & 26.8 & 68.1 & 47.8 & 26.7 & 67.2 \\
\hline & Pho-k ${ }^{\circledR}$ & 45.5 & 29.0 & 71.4 & 45.7 & 28.3 & 71.8 \\
\hline & Green top star ${ }^{\circledR}$ & 42.8 & 33.6 & 79.4 & 42.4 & 34.0 & 79.6 \\
\hline & Adenosine triphosphate ${ }^{\circledR}$ & 47.0 & 27.8 & 70.0 & 46.7 & 27.5 & 69.6 \\
\hline & Mixture of $\mathrm{K}_{2} \mathrm{O}+\mathrm{H}_{3} \mathrm{PO}_{4}+\mathrm{S}$ & 45.3 & 29.7 & 73.4 & 45.2 & 29.1 & 73.4 \\
\hline & Control (Tap water) & 50.8 & 26.4 & 64.7 & 50.6 & 25.8 & 65.0 \\
\hline \multirow{3}{*}{$\begin{array}{c}\text { L S D at } \\
0.05\end{array}$} & Planting dates & 2.6 & 1.6 & N S & 1.9 & 1.3 & NS \\
\hline & Treatments & 1.3 & 1.0 & 1.4 & 1.1 & 0.8 & 1.5 \\
\hline & Interaction & 1.0 & 1.5 & 2.0 & 1.3 & 1.2 & 2.2 \\
\hline
\end{tabular}


In this concern, Brandão (2007) postulated that spraying amino acids had many positive effects i.e. enhancing photosynthesis, absorbing and translocation of nutrients applied by foliar, encourage the root system more development and with more strength, moderating the hormonal activities of the plants, providing more tolerance to frost stress and more flowering of pepper plants. Abdel-Aziz and Geeth (2017) proposed that spraying amino acids at 3 $\mathbf{c m}^{3}$ I L under low temperature stress, significantly increased beginning of the flowering date (days after sowing) and pollen grains viability percentage in late peas planting. El-Sayed et al. (2015) pointed out that foliar application of eggplant with proline at the rate of $\mathbf{1 0 0}$ $\mathrm{mg} / \mathrm{L}$ significantly increased number of flowers/ plant, number of days to first flowers.

Respecting to the enhancing effects of foliar application with pho-k, adenosine triphosphate, green top star and mixture of potassium oxide, phosphoric acid and micronized sulpher as foliar treatments, these results are in the same line with reported by Abdel-Aziz and Geeth (2018) they referred that foliar spraying tomato plants with green top star at $2.5 \mathrm{~cm}^{3} / \mathrm{L}$ significantly increased the number of clusters, fruit set (\%), fruit length and fruit diameter. Abdel-Aziz and Afsah (2018) assumed that foliar spraying Cape gooseberry plants by solfan at the rate of $2 \mathrm{~cm}^{3} / \mathrm{L}$ significantly enhanced fruit set (\%), fruit length and fruit diameter.

\section{2-3-Effect of the interactions:}

Respecting to the effect of the interactions between the two factors used in this present study as shown in Table 5, the results illustrated that, planting date at the $15^{\text {th }}$ of September as well as foliar spraying by green top star followed by amino zied then the mixture of potassium oxide plus phosphoric acid and micronized sulpher were the best interactions treatments which produced the highest values of $50 \%$ flowering, number of flowers/ plant and fruit set $\%$ over the other two interactions treatments.

\section{3-Yield and its components of eggplant plants:}

3-1-Effect of planting dates:

The data presented at Table, 6 obviously showed that, the effect of planting dates, spraying with some stimulative treatments and their interactions on the fruit weight (g), yield and its components (ton/ fed.), the measurements indicate that, the $1^{\text {st }}$ planting date i.e. at the middle of September significantly increased all the previous traits of the eggplant plants as well as the lowest un-marketable fruits yield (ton/ fed.).

On the contrary, the $2^{\text {nd }}$ planting date i.e. at the middle of October registered the lowest values of the all previous traits as well as gave the highest increase in the un-marketable yield (ton/ fed.). This may be due to the higher solar radiation that prevailing at the time of the middle September, which enhanced the translocation of photosynthesis from source to sink and higher accumulation of photosynthesis in the fruits also, at this time, gets shorter cold condition at flowering and fruit development stages which reflects on growth, yield and its components.

On the other wise, the later planting date i.e. at the middle of October get extreme cold condition at these stages as mentioned before at meteorological data at Table, 1 which may be led to abscission of the flowers, fruits abortion and produce small fruits which led to reduce the all values of the previous traits specially total yield (ton/ fed.). These results reinforced with, Islam et al. 


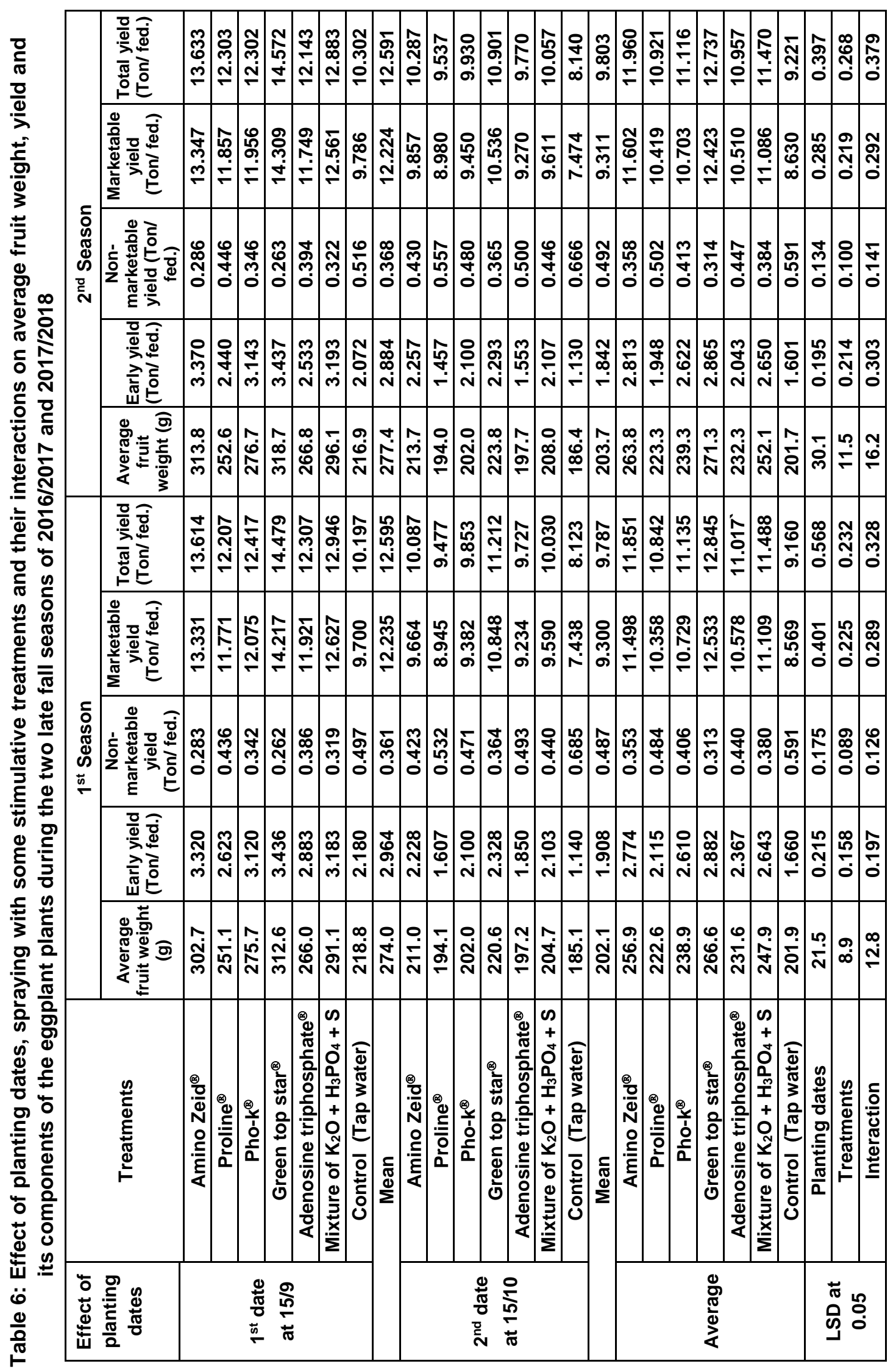


(2010) they pointed out that planting date at the $15^{\text {th }}$ of September gave significantly increased in individual fruit weight and total yield/ fed. of sweet pepper fruits as compared with the other one i.e. at the $15^{\text {th }}$ of October.

\section{3-2-Effect of spraying of some stimulative treatments:}

The data recorded in the same Table, 6 indicated that, the effect of spraying with some stimulative treatments i.e. amino zeid, proline, pho-k, adenosine triphosphate, green top star, mixture of potassium oxide plus phosphoric acid and micronized sulpher on average fruit weight (g), yield and its components (ton/ fed.). All foliar spraying treatments significantly increased the previous values of traits, in the same time the remarkable treatments were the green top star followed by amino zied then the mixture of potassium oxide plus phosphoric acid and micronized sulpher. The lowest result executed by foliar spraying of proline and adenosine triphosphate as compared to the control plants during the two late fall seasons, respectively.

Respecting to the favorable effects of amino acids and proline foliar treatments, the above findings were well which documented by many investigators as, Sarojnee et al. (2009) which they commented that amino acids can increase fertilizer absorption, improve uptake of nutrients and water content, reinforce the photosynthetic, dry matter sections, hence increase yield and quality of hot pepper. Mahmoud et al. (2017) investigated the foliar spraying of sweet pepper plants with the amino acids at the rate of $2 \mathrm{~g} / \mathrm{L}$. They found that this treatment significantly induced average fruit weight and total yield (ton/ fed.). ElSayed et al. (2015) mentioned that foliar application of eggplant with proline at the rate of $100 \mathrm{mg} / \mathrm{L}$ significantly increased of fruit yield /plant, number of fruits/plant, fruits yield and early fruits yield (ton/fed.).

Respecting to, the remarkable results of the pho-k, adenosine triphosphate, green top star and mixture of potassium oxide, phosphoric acid and micronized sulpher as foliar treatments are consistent with those of Abdel-Aziz and Geeth (2018) they referred that foliar spraying tomato plants with green top star at $2.5 \mathrm{~cm}^{3} / \mathrm{L}$ significantly increased fruit set (\%), fruit weight (g), early, marketable and total yield and significantly decreases the unmarketable yield (ton/ fed.). Abdel-Aziz and Afsah (2018) assumed that foliar spraying Cape gooseberry plants by solfan (liquid sulfur $70 \% \mathrm{SC}$ ) at rate of 2 $\mathrm{cm}^{3} / \mathrm{L}$ significantly enhanced fruit weight with calyx (g), early and total yield (tonl fed.). Hegazi et al. (2017) mentioned that foliar application by potassium as $\mathrm{K}_{2} \mathrm{O}$ at rate of $200 \mathrm{ppm} / \mathrm{L}$ gave significantly improved the total weight of fruits/ plant (g) of sweet pepper. Abdel-Hakim et al. (2012) decided that foliar application of snap bean plants with adenosine triphosphate at rate of $180 \mathrm{ppm}$ significantly increased average pod weight/ plant, marketable yield and significantly decreased the unmarketable yield (ton/fed.).

\section{3-3-Effect of the interactions:}

Concerning to, the effect of the interactions between the two planting dates and foliar spraying with some stimulative treatments on the eggplant plants to study the influence on the fruit weight, yield and its components (ton/ fed.). The data at the same Table, 6 clearly established that, the $1^{\text {st }}$ planting date at the middle of September as well as foliar spraying with green top star followed by amino zied then the mixture of potassium oxide plus phosphoric acid and micronized sulpher led to a marked stimulative effect of all previous 
characters and decreased the unmarketable fruit yield.

On the contrast, the lowest records on average fruit weight $(\mathrm{g})$, the marketable and total yield and the highest increase on the un-marketable yield (ton/ fed.), were obtained with the interactions treatment between the $2^{\text {nd }}$ planting date at $15^{\text {th }}$ of October (late season) and foliar spraying with each of proline then adenosine triphosphate as compared to the control treatment, these data held true in the two late fall seasons, respectively.

Moreover, the total yield could be considered to be the reflection of the all growth features, therefore the increases in the eggplant fruit yield and its components can be explained by the significant increases due to the greatest values of the vegetative growth characters as mentioned before in Table, 4 during the two growing late fall seasons. The previous findings coincided with that obtained by AbdelHakim et al. (2012) who mentioned that the interaction between the $1^{\text {st }}$ sowing date i.e. at the $25^{\text {th }}$ of October on snap bean plants and foliar application with adenosine triphosphate at rate of $\mathbf{1 8 0}$ ppm significantly increased the highest mean values of pod weight/plant, marketable yield (ton/fed.) and significantly decreased the unmarketable yield (ton/fed.). Whereas, the lowest of values of the previous traits were obtained with the interactions of the $2^{\text {nd }}$ sowing date $i . e$. at $15^{\text {th }}$ of November and foliar application with adenosine triphosphate at rate of $60 \mathrm{ppm}$.

\section{4-Chemical composition of} eggplant fruits:

\section{4-1-Effect of planting dates:}

Data of the total chlorophyll contents ( $\mathrm{mg} / \mathbf{1 0 0 ~} \mathrm{g}$ fresh weight) contents in the fresh leaves, ascorbic acid $\mathrm{mg} / 100 \mathrm{~g}$ (fresh weight) contents in the fresh fruits, the total phenol (mgl g) and the total sugars (\%) contents in dry fruits, the cold injury index (\%) and the cold tolerance index (\%) as affected by planting dates, spraying with some sttimulative treatments and their interactions are shown in Table, 7, those data indicated that, the highest values of the previous chemical composition were obtained from the eggplant plants planted at the $15^{\text {th }}$ of September. However, when the planting was delayed until the middle of October, those characters showed the lowest values.

On the other hand, no significant difference was obtained in ascorbic acid and total phenol content between the $1^{\text {st }}$ and the $2^{\text {nd }}$ planting dates in the two late fall seasons, respectively. These results are came to the same conclusion with findings of Singh et al. (2015) which they investigated that planting date at the $15^{\text {th }}$ of September significantly increased the total soluble solids and ascorbic contents as compared to the $3^{\text {rd }}$ planting date at the $15^{\text {th }}$ of October of tomato fruits.

\section{4-2-Effect of spraying of some stimulative treatments:}

Regarding to the results of the previous chemical composition i.e. the total chlorophyll, ascorbic acid, the total phenol and the total sugars, the cold injury index and the cold tolerance index of eggplant plants are presented in the same Table, 7 as affected by different spraying treatments, the data showed that the maximum values were achieved by foliar spraying green top star followed by amino zied then the mixture of potassium oxide plus phosphoric acid and micronized sulpher as compared to the rest treatments.

With reference to, ascendant effects of the amino acids and proline foliar treatments, amino acids help to increase 


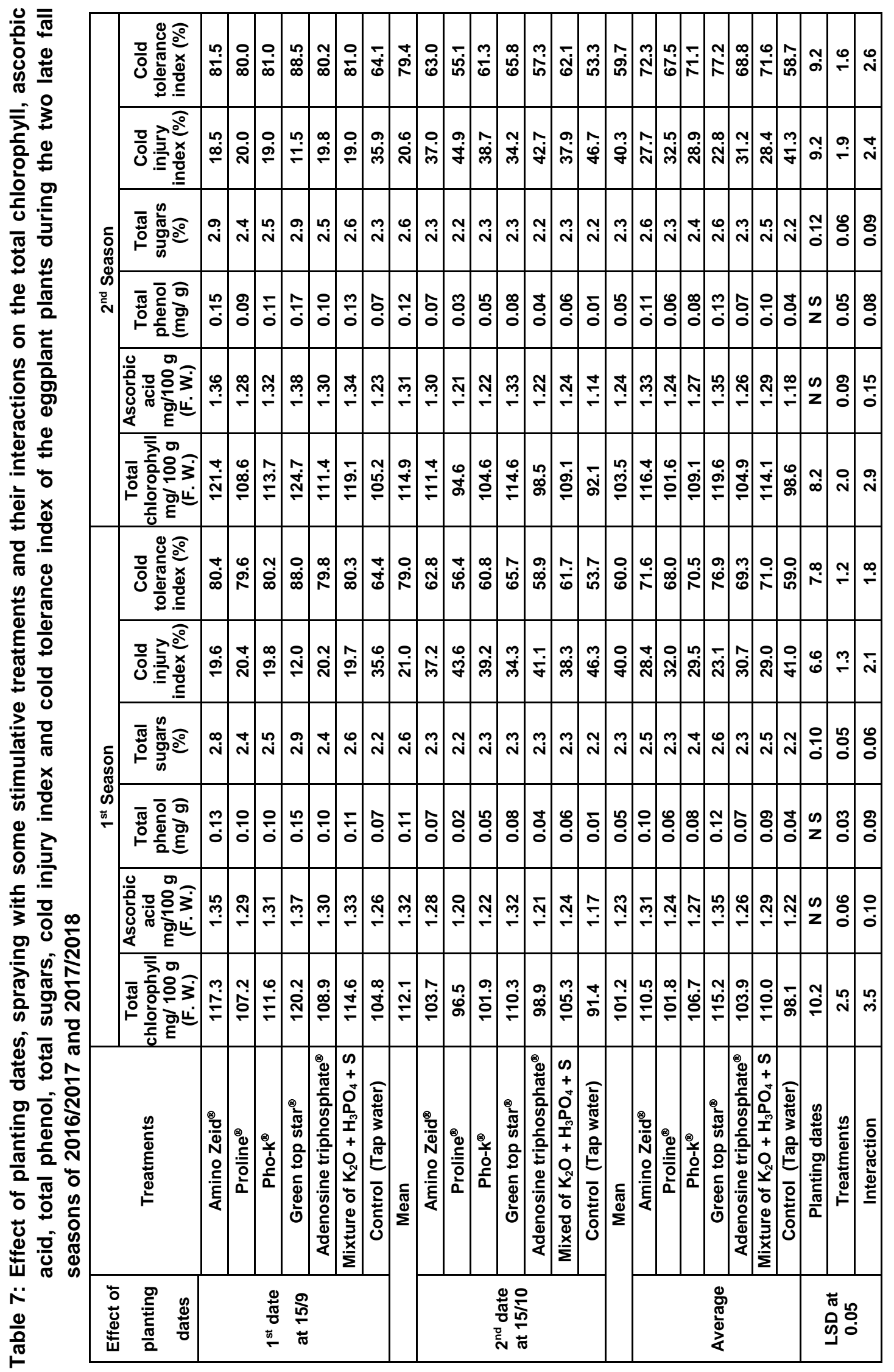


the chlorophyll concentration in the plants, leading to a higher degree of photosynthesis, which in turn leads to even more available energy. Amino acids also, help many symbiotic processes that improve many aspects of plants its can be activators or precursors of phytohormones and growth substances like, L-tryptophan which is a precursor for auxin synthesis. Consequently, auxin leads to an increase in total phenol contents in the eggplant plants.

In this respect also, there was higher relationship between total phenolics and higher antioxidant capacity in the plants. Total phenolics compounds play main role of protect the plants against abiotic stresses i.e. low temperature and enhanced the production and quality of tomato fruits and are potent reactive oxygen species as well as scavengers and inhibitors of lipid peroxidation as mentioned by Pellati et al. (2004).

It was also, noted from the previous results that, increasing the ability of plants to withstand the low temperatures is accompanied by an increase in biochemical commodes within plants such as ascorbic acid, total sugars and especially total phenols as shown in Table, 7, (Yogendra et al. 2017). These results are in agreement with Mahmoud et al. (2017) who recorded that, foliar spraying of sweet pepper plants with the amino acids at rate of $2 \mathrm{~g} / \mathrm{L}$ resulted in significant positive effects on all fruit quality parameters i.e. the total chlorophyll, ascorbic acid, the total phenol and the total soluble solids as compared to the control (untreated plants). El-Sayed et al. (2015) mentioned that foliar application with proline at the rate of $100 \mathrm{mg} / \mathrm{L}$ significantly increased the ascorbic acid and the total soluble solids of eggplant fruits.

With respect to, the stimulative effects of pho-k, adenosine triphosphate, green top star and mixture of potassium oxide, phosphoric acid and micronized sulpher as foliar treatments, the present results were agreed with that reported by AbdelAziz and Geeth (2018) generalized that foliar spraying tomato plants with green top star at $2.5 \mathrm{~cm}^{3} / \mathrm{L}$ significantly increased total chlorophyll and the total sugars (\%).

\section{4-3-Effect of the interactions:}

The data in the same Table, 7 clearly show that, the distinguished interactions on the total chlorophyll, ascorbic acid, the total phenol and the total sugars, the cold tolerance index, decreasing the cold injury index of eggplant plants was occurred between the $1^{\text {st }}$ planting date at the middle of September as well as foliar spraying with green top star followed by amino zied then the mixture of potassium oxide plus phosphoric acid and micronized sulpher were led to a stimulative effect of all the previous characters as well as specially decreased the cold injury index (\%) as compared with the other interactions treatments.

\section{Conclusions}

It could be concluded that, under the conditions of this investigation, it can be recommended by cultivate the eggplant plants Black berry $\mathrm{F} 1$ during the late fall season at the most appropriate planting date i.e. the middle of September as well as spraying the plants by green top star at $2.5 \mathrm{~cm}^{3} / \mathrm{L}$ followed by amino zied at $0.5 \mathrm{~g} / \mathrm{L}$ then the mixture consists of potassium oxide at $2.5 \mathrm{~cm}^{3}$ plus phosphoric acid at $1.5 \%$ and micronized sulpher at $2.5 \mathrm{~g} / \mathrm{L}$, while the preferable one was green top star which applied after 15 days from transplanting and repeated every 15 day intervals at eight times to protect the eggplant plants from the chilling injury during the late fall season and led to obtain marked vegetative growth, number of flowers/ plant, fruit set \%, as well as the marketable and total yield (ton/ fed.), best 
fruit quality, the highest percentage each of the cold tolerance index and decreasing the cold injury index especially in the later planting date i.e. at the middle of October.

\section{REFERENCES}

A.O.A.C. (2005). Official Methods of Analysis. $18^{\text {th }}$ Ed. Association of Official Agric. Chemists, Washington, DC, USA.

Abdel-Aziz, M. A. and A. F. E. Afsah (2018). Effect of spraying Cape gooseberry (Physalis peruviana L.) plants with some natural and safety compounds on growth, fruit yield and its quality as well as its reflects on some pests and mites infestation Egyptian J. Appl. Sci., 33 (3):133 - 155.

Abdel-Aziz, M. A. and R. H. M. Geeth (2017). Effect of spraying by some substances on low temperature stress for growth and productivity in late peas (Pisum sativum $\mathrm{l}$.) planting under the middle Egypt region conditions. J. Plant Production, Mansoura Univ., 8 (8): 859 - 867.

Abdel-Aziz, M. A. and R. H. M. Geeth (2018). Response of tomato (Solanum lycopersicum L.) plants to some physiological treatments on reducing nitrate and nitrite accumulation in vegetative and productive organs, yield and its quality. Egyptian J. Appl. Sci., 33 (5): 205 - 237.

Abdel-Hakim, W. M., Y. M. M. Moustafa and R. H. M. Gheeth (2012). Foliar application of some chemical treatments and planting date affecting snap bean (Phaseolus vulgaris L.) plants grown in Egypt. J. Horti. Sci., and Ornamental Plants, 4 (3): 307-317.

Alexander, S. L., B. Aušra and B. P. D. Česlovas (2012). Chilling injury in chilling-sensitive plants: a review. Agric., 99 (2): 111-124.

Boras, M., R. Zidan and W. Halloum (2011). Effect of amino acids on growth, production and quality of tomato in plastic greenhouse. Tishreen Univ. J. Res. and Sci., Studies. Biolog Sci., Series, 33(5):229238.

Brandão, R. P. (2007). Importance of Amino acids in agriculture. Informativo Bio Soja, São Joaquim da Barra, 5:6-8.

Bricker, B. (1991). MSTATC: A micro computer program from the design management and analysis of agronomic research experiments. Michigan State Univ. USA.

Chapman, H. D. and R. T. Pratt (1961). Methods of Analysis for Soils, Plants and Water. Univ. of California, Div. Agric Sci., pp: 169.

Dubois, M., K. M. Gilles, J. K. Hamilton, P. A. Robers and F. Smith (1975). Calorimetric method for determination of sugars and related substances. Analyst., Chem. 28:350.

El-Sayed, Hala A., A. E. M. Eata and A. K. A. Khater (2015). Physiological studies on eggplant (Solanum melongenal.): decreasing the effect of salinity by some foliar application substances on eggplant. J. Plant Production, Mansoura Univ., 6 (7): 1153-1168.

Geeth, R. H. M. and M. A. Abdel-Aziz (2017). Response growth and productivity of snap bean (Phaseolus vulgaris L.) plants to organic manure fertilization, irrigation regimes and foliar spraying with ascorbic acid under newly reclaimed soil condition. Menoufia J. Plant Prod., 2 (8): 359 381.

Guo, W., N. Hussain, L. Zongsuo and Y. Dongfeng (2016). Magnesium deficiency in plants: An urgent problem. The Crop J., 4:83 - 91.

Harlan, D. S. and P. M. Raymond (2015). Managing weather and climate risks to agriculture in North America, Central America and the Caribbean. Weather and Climate Extremes, 10:50-56.

Hegazi, Amira M., A. M. El-Shraiy and A. A. Ghoname (2017). Growth, yield and 
nutritional quality of sweet pepper plants as affected by potassium and phosphate fertilizers varying in source and solubility. Current Sci., International, 6 | Issue: 02| April-June| 445-457.

Inthichack, P., Y. Nishimura and Y. Fukumoto (2013). Diurnal temperature alternations on plant growth and mineral absorption in eggplant, sweet pepper, and tomato. Horti., Environment and Biotechnology, 54: 37-43.

Islam, M., S. Saha, H. Akand and A. Rahim (2010). Effect of sowing date on the growth and yield of sweet pepper (Capsicum annuum L.). (C F Comp., Search).

Mahmoud, M., M. El-Hamady, G. B. Ahmed, M. Mahmoud, M. H. Ashour and $H$. M. Hossam (2017). Influence of mineral fertilization in combination with K-humate, amino acids and sodium selenite on growth, chemical composition, yield and fruit quality of sweet pepper plant. Middle East J. Agric. Res., 06 | Issue : 02 | April-June l:433-447.

Marschner, P. (2012). Marschner's mineral nutrition of higher plants, $3^{\text {rd }}$ Ed.; Academic Press: London, UK, 178-189.

Nagata, M. and I. Yamashita (1992). Simple method for simultaneous determination of chlorophyll and carotenoids in tomato fruit. J. Japan Soc. Food Sci., Technol., 39: 928-932.

Njira, K. O. and J. Nabwami (2015). A review of effects of nutrient elements on crop quality. African J. Food, Agric., Nutr., Development, 15 (1): 9777-9793.

Page, A. L., R. H. Miller and D. R. Keeney (1982). Methods of Chemical Analysis. Part 2: Chemical and Microbiological Properties (2 ${ }^{\text {nd }}$ Ed.). Am. Soc. Agron., Inc. and Sci. Soc. of America, Inc. Publi., Mad ison, Wisconsin, USA.
Pellati, F. S., L. Benvenuti, M. Magro, M. Melegari and F. Soragni (2004). Analysis of phenolic compounds and radical scavenging activity of Echinacea spp. J. Pharm. Biomed. Anal. 35:289-301.

Sarojnee, D. Y., B. Navindra and S. Chandrabose (2009). Effect of naturally occurring amino acid stimulants on the growth and yield of hot peppers (Capsicum annum L.). J. Animal and Plant Sci., 5 (1): 414-424.

Singh, A., P. K. Jain, H. L. Sharma and Y. Singh (2015). Effect of planting date and integrated nutrient management on the production potential of tomato (Solanum lycopersicon Mill.) under polyhouse condition. J. Crop and Weed, 11 (Special Issue):28-33.

Szabados, L. and A. Savoure (2010). Proline: a multifunctional amino acid. Trends Plant Sci., 15: 89-97.

Umesh, K. K., K. B. Vijay, K. Nikunj, P. Neha and A. G. Baljibhai (2015). Antioxidant and nutritional components of eggplant (Solanum melongena L.) fruit grown in Saurastra region. Int. Curr. Microbiol. App. Sci., 4(2): 806-813.

Wettasinghe, M. and F. Shahidi (1999). Evening primrose meal: a source of natural antioxidants and scavenger of hydrogen peroxide and oxygen derived free radicals. J. Agric., Food Chemistry, 47: 1801-1812.

Wilson, J. M. and J. A. Greaves (1990). Assessment of chilling sensitivity by chlorophyll fluorescence analysis. In: Chilling injury of horticultural crops. C.Y. Wang (Ed.). CRC Press, London. pp. 130-139.

Yogendra, K. M., D. S. Khurana, K. Nirmaljit and S. Kulbir (2017). Phenolic compounds enhanced low temperature stress tolerance in tomato (Solanum lycopersicum L.). British J. Appl. Sci., and Technol., 20(3):1-9. 
خفض التأثيرات الضاره لارجة الحرارة المنخفضة على الباذنجان خلال العروة الخريفة المتأخرة بأستخدام بعض المعاملات الفسيولوجية وأنعكاس ذلك على النمو والمحصول ومكوناته و جودة الثمار فى ميعادين للزراعة

\author{
مدحت أحمد عبد العزيز، ربيع حسن محمد غيث

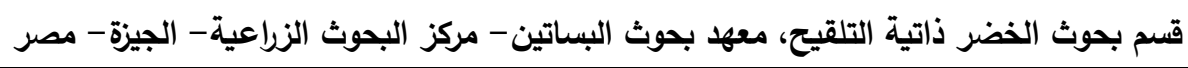

الملخص العربى أحس هذه

أجريت هذه التجربة بمحطة بحوث سدس - مركز البحوث الزراعية - محافظة بنى سويف خلال العروة النيلية المتأخرة لموسمى 2017/2016 و 2017 2018 بهاف تحديد أفضل ميعاد لزراعة شتلات الباذنجان فى العروة النيلية المتأخرة حيث تمت الزراعه فى ميعادين هما الخامس عشر من سبتمبر و الخامس عشر من أكتوبر كذلك تعديد أفضل معاملات

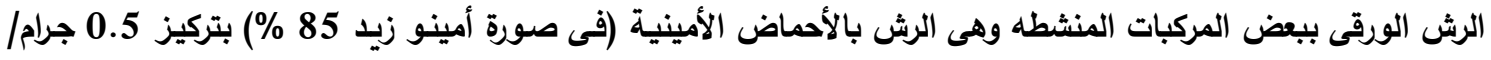

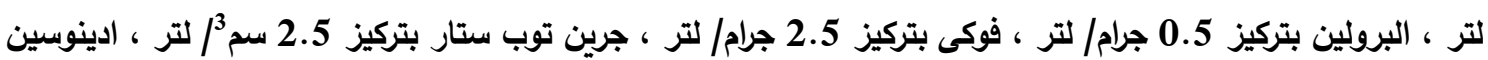

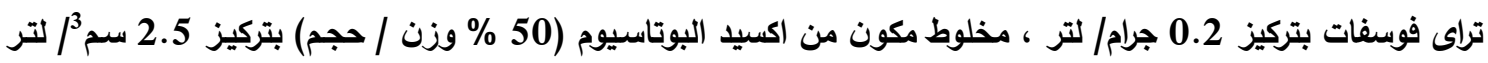

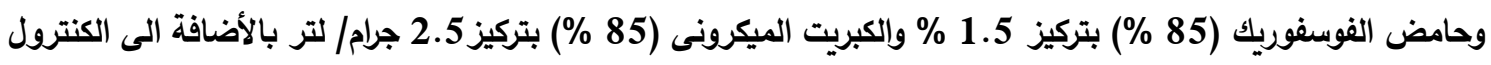

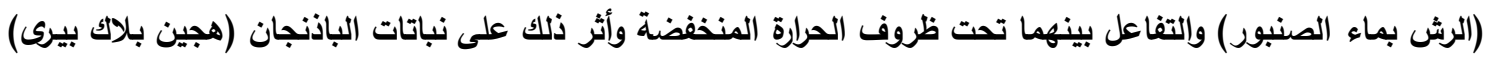
من حيث النمو والتزهير ونسبة العقد \% ومتوسط وزن الثمرة والمحصول ومكوناته وبعض الصفات الكيماوية للثمار ودليل

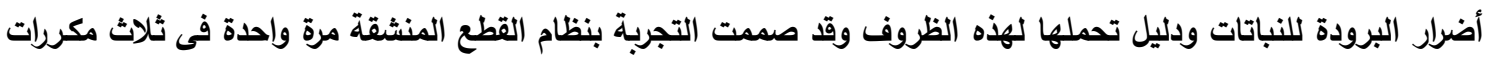
حيث وضعت مواعيد الزراعة فى القطع الرئيسية و وزعت معاملات الرش المختلفة عشوائياً فى القطع المنثقة مرة واحدة. وقد أظهرت النتائج المتحصل عليها مايلى:-

وجد ان أفضل ميعاد لزراعة نباتات الباذنجان تحت الظروف الجوية لهذه التجربة هو منتصف شهر سبتمبر حيث أدى ألى

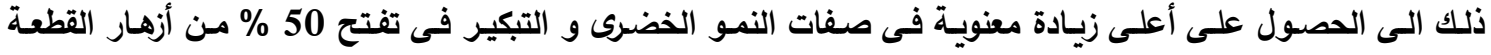

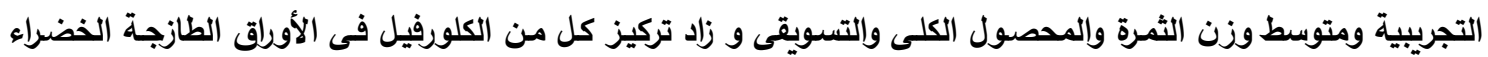

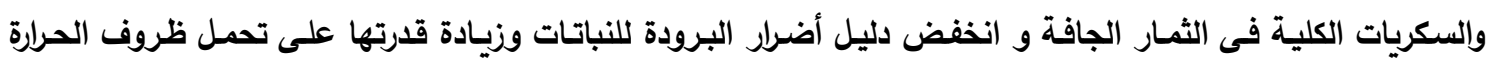

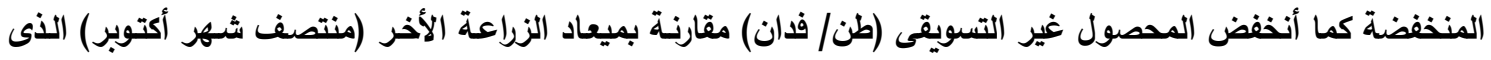
ادى الى أنخفاض قيم كل الصفات السابقة كما أدى الى أرتفاع المحصول غير التسويقى و ارتفع بثدة دليل ضرر البرودة

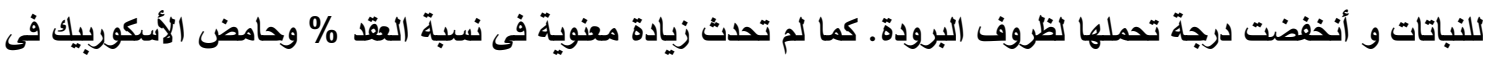

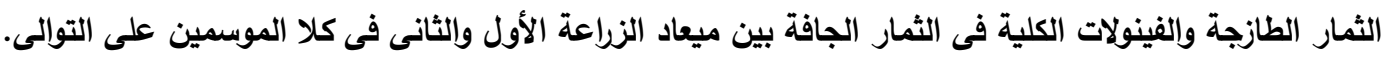
كما ادى الرش الورقى لنباتات الباذنجان بمادة جرين توب ستار بتركيز 2.5 سم²/ لتر يليها الرش بالأحماض الأمينية

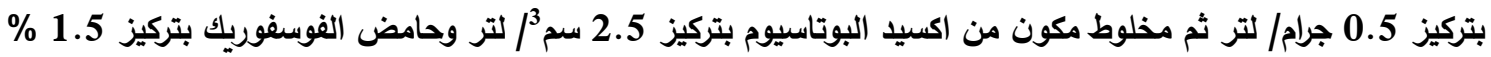

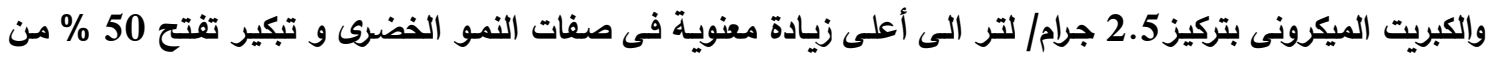

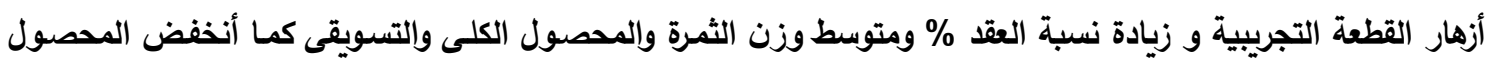

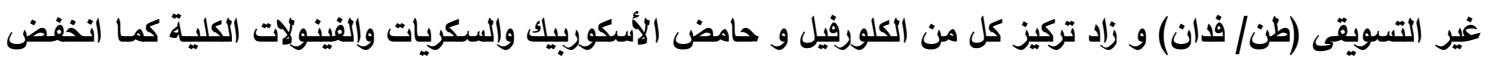


دليل أضرار البرودة على النباتات وزادت درجة تحملها للبرودة مقارنة بمعاملة الرش بالبرولين بتركيز 0.5 جرام/ لتر يليها الرش بمركب ادينوسين تراى فوسفات بتركيز 0.2 جرام/ لتر .

أما بالنسبة الى نتائج التفاعل بين عاملى الدراسة (مواعيد الزراعة والرش الورقى ببعض المواد المنشطه) تحت ظروف

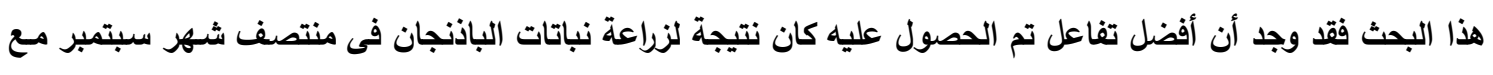

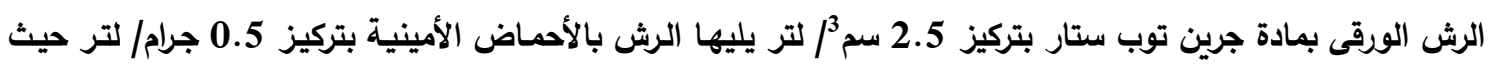

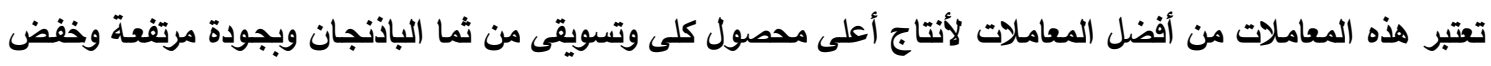
التأثير السىء للبرودة على النباتات والثمار ألى اقل حد ممكن.

ويمكن التوصية بزراعة نباتات الباذنجان تحت ظروف الموسم الخريفى المتأخر فى منتصف شهر سبتمبر والرش بمادة

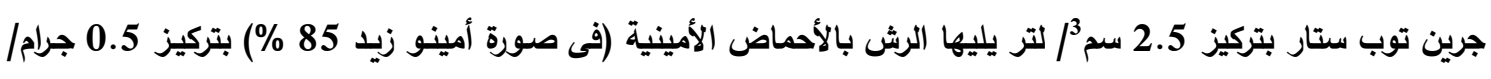

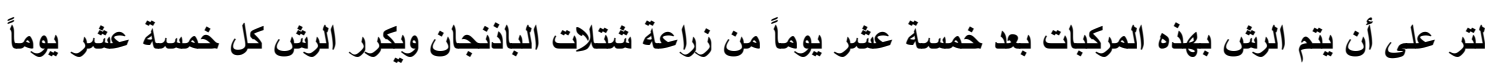

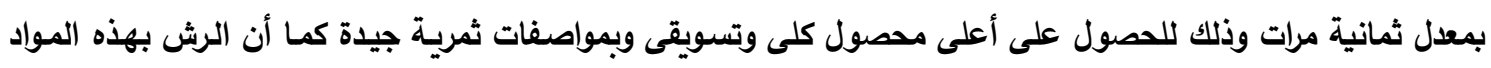

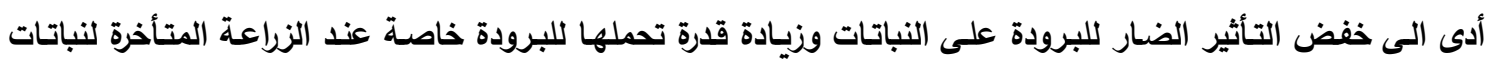

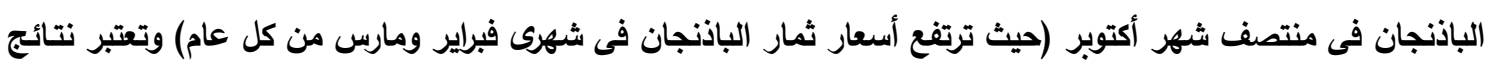

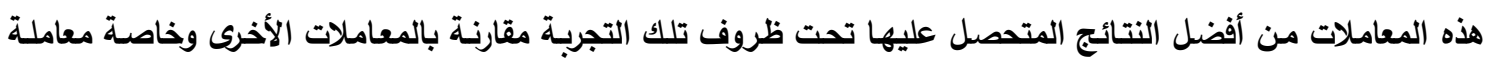

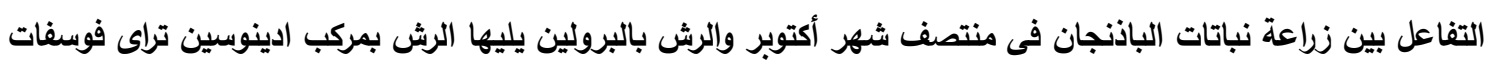

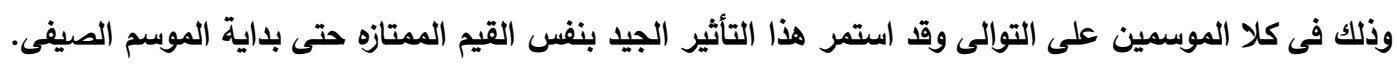
الكلمات الداله: الباذنجان - مواعيد زراعة - حرارة منخفة - جرين توب ستار - جودة الثمار - اضرار البرودة - تحمل البرودة.

\author{
أسماء السادة المحكمين

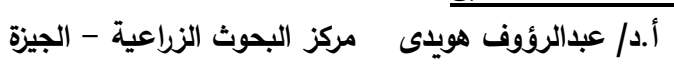

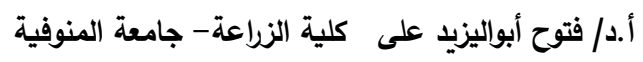

